\title{
Four Years' Experience with Dapsone as Prophylaxis Against Leprosy*
}

\author{
Y. OTSYULA, C. IBWORO AND H. J. CHUM \\ East African Leprosy Research Centre, John Lowe Memorial, P.O. Box 1044, \\ Busia, Tororo, Uganda
}

\begin{abstract}
Dapsone has been used as a prophylaxis against leprosy in the schools in Samia (trial area). The results obtained suggest that the drug is effective in protecting children against leprosy. This agrees well with the findings of Dharmendra et al. (1965). The major limitations are those of administration. No side-effects were noted during the trial.
\end{abstract}

\section{Introduction}

The value of dapsone as a prophylaxis against leprosy has been advocated by some leprosy workers (Dharmendra et al., 1965; Wardekar, 1967) and denied by others. Since Mycobacterium leprae have been found in human mammary glands and in human milk (Pedley, 1967, 1968), more evidence concerning the efficacy of dapsone as a prophylactic against leprosy is badly needed.

The East African Leprosy Research Centre, therefore, planned a controlled trial in the two adjacent areas of Samia and Bunyala Locations (Fig. 1) to ascertain whether dapsone is an effective prophylactic agent against leprosy. This paper discusses the trial carried out in schools in these two areas, covering the period between February, 1963, and December, 1967.

\section{Method}

An intensive survey was carried out in 1963 in Samia and Bunyala Locations, in which 28,873 people of all ages were examined clinically for signs of leprosy, special attention being paid to the schoolchildren.

The names of the children in primary classes I to IV in the two areas were recorded in special registers. In Samia there were 20 schools with a total of 3380 children; and in Bunyala Location, 14 schools, and 1393 children.

In Samia Location, dapsone was issued twice a week by the headmasters of the schools to all the pupils. No dapsone was given in Bunyala schools. All the schools in the two areas were regularly visited by a research officer from the Leprosy Research Centre and fortnightly during the period of the trial.

\footnotetext{
* Approved for publication March 1971.
} 


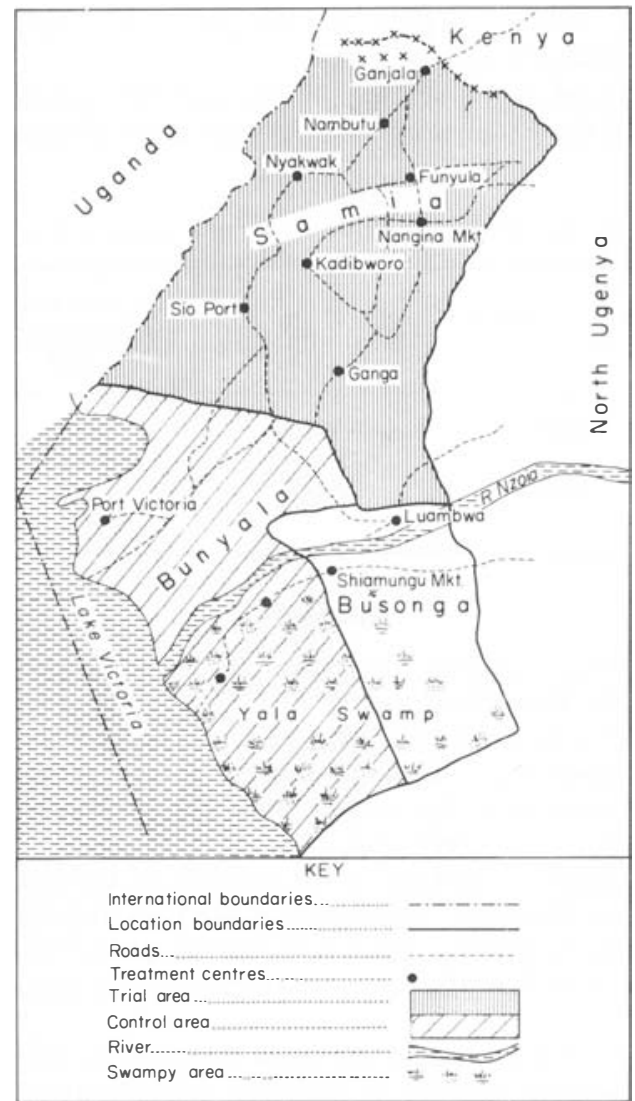

Fig. 1. Map showing locations of Samia and Bunyala. Treatment and control areas are marked.

\section{Results}

Among the 28,873 persons examined in the preliminary survey, 1860 were found to have leprosy, giving a prevalence rate of 64.4 per $1000 ; 73.8 \%$ of these patients had tuberculoid leprosy and the remainder lepromatous or borderline forms.

The prevalence rates among schoolchildren in the two locations were similar, namely 6.5 per 1000 in Bunyala and 6.2 per 1000 in Samia. At the beginning of the trial there were 9 known cases of leprosy in the Bunyala schools and 21 in the Samia schools. During the period of the trial, out of the 3366 children in the Samia schools who had regularly taken prophylactic dapsone, 4 contracted leprosy, whereas 13 out of 1370 among the non-protected children in the Bunyala schools were diagnosed as having contracted leprosy. The incidence rates for the 3 years are thus 1.2 per 1000 and 9.5 per 1000 respectively, an 8 -fold difference 
attributable, in our opinion, solely to the protective value of the dapsone regularly administered to the former group.

All patients diagnosed in the schools before and after the trial had tuberculoid leprosy (Table 1). All the patients discovered were given treatment.

TABLE 1

Showing two groups of children (in trial and control areas)

\begin{tabular}{lcccc}
\hline \multicolumn{1}{c}{ Location } & $\begin{array}{c}\text { No. of children } \\
\text { before trial }\end{array}$ & $\begin{array}{c}\text { No. of children } \\
\text { at the follow-up }\end{array}$ & $\begin{array}{c}\text { No. with leprosy } \\
\text { at beginning of } \\
\text { trial }\end{array}$ & $\begin{array}{c}\text { No. developing } \\
\text { leprosy during } \\
\text { trial }\end{array}$ \\
\hline $\begin{array}{l}\text { Samia } \\
\text { (trial group) }\end{array}$ & 3380 & 3366 & 21 & 4 \\
$\begin{array}{l}\text { Bunyala } \\
\text { (control group) }\end{array}$ & 1393 & 1370 & 9 & 13 \\
\hline
\end{tabular}

\section{Discussion}

The results obtained confirm that dapsone does protect children against leprosy. In their study, Dharmendra et al. (1965) concluded that the prophylactic value of dapsone begins to show 9 months after starting to take the drug, but that once infection has taken place, dapsone confers no protection against leprosy. It is possible that the children in the present trial who were found to have leprosy had been infected before the trial began.

The original prevalence of leprosy in the schools in the two groups in Bunyala and Samia was similar. However, at the end of the trial, the differences in the two areas were statistically significant $\left(\chi^{2}=7.743\right.$ and $\left.0.01>P 0.005\right)$. The questions remaining are: How long has the drug to be taken-for life? Will there be any toxic effects?

In the trial period of 3 years and 10 months, no toxic effects were observed. Kidney and liver function tests on 52 children selected at random in the Samia trial gave normal values.

It would appear from the results that dapsone can be used to protect children whose mothers have leprosy. Since the effect of the drug begins to show after about 9 months, it would be better to give the child a small dosage ( $25 \mathrm{mg}$ twice a week) as soon as it is weaned, since during lactation the child is apparently protected by the dapsone excreted in the mother's milk.

\section{Acknowledgements}

We should like to acknowledge our debt to the former director of this Centre, Dr. S. M. Ross, for planning and carrying out part of this exercise; and to thank the head-teachers of both Samia and Bunyala schools for keeping the records during the trial.

\section{References}

Dharmendra, A. I. M., Noordeen, S. K. and Ramanujam, K. (1965). Prophylactic value of DDS against leprosy. Lepr. India 37, 447.

Pedley, J. C. (1967). The presence of Myco. leprae in human milk. Lepr. Rev. 38, 239.'

Pedley, J. C. (1968). Presence of Myco. leprae in the nipple secretion and lumina of the hypertrophied mammary gland. Lepr. Rev. 39, 67.

Wardekar, R. V. (1967). DDS prophylaxis against leprosy. Lepr. India 39, 155. 